\title{
PROPERTIES OF THE GENOME IN NORMAL AND SV40 TRANSFORMED WI38 HUMAN DIPLOID FIBROBLASTS
}

\section{Composition and Metabolism of Nonhistone Chromosomal Proteins}

\author{
M. O. KRAUSE, ${ }^{1}$ L. J. KLEINSMITH ${ }^{2}$ and G. S. STEIN ${ }^{1 *}$ \\ 1 Department of Biochemistry, University of Florida, Gainesville, Fla 32610, and the \\ ${ }^{2}$ Department of Zoology, University of Michigan, Ann Arbor, Mich. 48104, USA
}

\begin{abstract}
SUMMARY
The composition and metabolism of nonhistone chromosomal proteins associated with the genome of normal and SV40 transformed WI38 human diploid fibroblasts were examined. Evidence is presented which indicates variations in the relative protein content, specific activity and phosphorylation of several defined molecular weight classes of these chromosomal polypeptides. In addition, it is shown that blocking DNA replication with cytosine arabinoside does not inhibit the incorporation of ${ }^{3} \mathrm{H}$-leucine into nonhistone chromosomal proteins of SV40 transformed cells. The possibility that the nonhistone chromosomal proteins of human diploid fibroblasts transformed by SV40 virus may be involved in the regulation of viral induced alterations in gene expression is discussed.
\end{abstract}

Infection and transformation of eukaryotic cells with RNA and DNA viruses is reflected by modifications at the biochemical as well as morphological levels $[3,21,38]$. Such changes include variations in growth control [25, 40], cell surface architecture [22], cellular enzymes [6], and nuclear as well as plasma membrane associated antigens $[7,37]$. Since these virusinduced cellular changes reflect alterations in gene expression, one might anticipate modifications in the macromolecules which comprise the genome and interact with DNA to regulate its function.

The genome of eukaryotic cells is a nucleoprotein complex consisting primarily of DNA and two major classes of chromosomal proteins, histones and nonhistone

\footnotetext{
* To whom reprint requests should be addressed.
}

chromosomal proteins. Histones have been shown to be involved in repression of DNAdependent RNA synthesis [1, 11], maintenance of chromatin structure $[2,10,19]$ and cytodifferentiation [2, 19]. Recent evidence indicates that nonhistone chromosomal proteins may recognize specific gene loci and play a key role in the regulation of gene readout $[9,13,14,26-31,39,41]$. In the present studies, the nonhistone chromosomal proteins associated with the genome of normal and SV40 transformed WI38 human diploid fibroblasts were examined with respect to their composition, rates of synthesis and phosphorylation. A subsequent report will describe differences in the composition, binding and metabolism of histones in these cells [17]. 


\section{MATERIALS AND METHODS}

\section{Cell culture}

Human diploid WI38 fibroblasts and SV40 transformed WI38 fibroblasts were grown in monolayer culture in Eagle's basal medium (BME) containing $10 \%$ fetal calf serum. The cells were cultivated in 1 liter Blake bottles and incubated in a moist $\mathrm{CO}_{2}$ incubator. All experiments were carried out utilizing exponentially growing normal and transformed cells. Criteria for exponential growth included determinations of cell growth rate and percentage of the cell population undergoing DNA replication. The normal human diploid fibroblasts utilized in these studies range from passage 28 to 32 . This is an important consideration since age-dependent modifications in the metabolism of chromosomal proteins have been observed in late passage human diploid fibroblasts [35]. SV40 transformed WI38 cells are an established line (2RA) obtained from Dr Vincent J. Cristofalo, Wistar Institute, Philadelphia, Pa.

\section{Labelling with radioisotopes}

The synthesis and phosphorylation of nonhistone chromosomal proteins in normal and SV40 transformed WI38 human diploid fibroblasts was determined by labelling cells either with ${ }^{3} \mathrm{H}$-L-leucine alone or with ${ }^{3} \mathrm{H}-\mathrm{L}$-tryptophan and ${ }^{32} \mathrm{P}$.

(a) Labelling with ${ }^{3} \mathrm{H}$-L-leucine. Medium was removed from the monolayer cultures and cells in each flask were incubated at $37^{\circ} \mathrm{C}$ for 60 min with $15 \mathrm{ml}$ of L-leucine-free BME containing ${ }^{3} \mathrm{H}-\mathrm{L}$-leucine $(5 \mu \mathrm{Ci} / \mathrm{ml}, 41.2 \mathrm{Ci} / \mathrm{mM})$ and $2 \%$ fetal calf serum. Each sample consisted of $3 \times 10^{7}$ cells ( 3 1 Blake culture flasks). Isotope incorporation was terminated by pouring off the labelling medium and washing the monolayers 3 times with $15 \mathrm{ml}$ of cold $\left(4^{\circ} \mathrm{C}\right)$ Earle's balanced salt solution.

(b) Labelling with ${ }^{3} \mathrm{H}$-L-tryptophan and ${ }^{32} \mathrm{P}$. For the double labelling experiments, the medium was removed from the monolayer cultures and cells in each flask were incubated at $37^{\circ} \mathrm{C}$ for $60 \mathrm{~min}$ with $15 \mathrm{ml}$ of L-tryptophan-free and phosphate-free BME containing ${ }^{3} \mathrm{H}-\mathrm{L}$-tryptophan $(5 \mu \mathrm{Ci} / \mathrm{ml}, 1.65 \mathrm{Ci} / \mathrm{mM})$, ${ }^{32} \mathrm{P}(83 \mu \mathrm{Ci} / \mathrm{ml})$ and $2 \%$ fetal calf serum. Each sample consisted of $3 \times 10^{7}$ cells ( 31 Blake culture flasks). Isotope incorporation was terminated and monolayers were washed as described above.

All isotopes were obtained from New England Nuclear Corporation, Boston, Mass.

\section{Isolation of nuclei and chromatin}

Preparation of nuclei was carried out at $4^{\circ} \mathrm{C}$ and the details of the procedure have been previously described [32]. Cells were harvested by scraping with a rubber policeman, washed 3 times with Earle's balanced salt solution and lysed with $80 \mathrm{mM} \mathrm{NaCl}$, $20 \mathrm{mM}$ EDTA, $1 \%$ Triton X-100 (pH 7.2). Nuclei were pelleted by centrifugation at $1000 \mathrm{~g}$ for $4 \mathrm{~min}$ and washed 3 times with the lysing medium. This was followed by two washes with $0.15 \mathrm{M} \mathrm{NaCl}, 0.01 \mathrm{M}$ Tris (pH 8.0). Nuclei isolated in this manner are free of cytoplasmic contamination when examined by phase contrast microscopy. Both cell lysis and washing of nuclei were carried out in the presence of $50 \mu \mathrm{g} / \mathrm{ml}$ of 1-L-tosylamide-2-phenyl-ethylchloromethyl-ketone (TPCK) [36] to inhibit proteolytic degradation. The presence of the inhibitor resulted in higher nonhistone chromosomal protein: histone ratios indicating that nonhistone chromosomal proteins were more susceptible to proteolysis than histones. In the absence of the inhibitor, some nuclear proteolysis occurred during isolation of nuclei and chromatin and was particularly pronounced in SV40 transformed cells.

Chromatin was isolated as previously described by Stein \& Thrall [33]. The protein:DNA ratios of the chromatin preparations (normal and transformed cells) were 2.4 and the nonhistone chromosomal protein : histone ratios were 1.8 .

\section{Polyacrylamide gel electrophoretic fractionation of chromosomal proteins}

Chromatin was dissociated by homogenization in $1.5 \mathrm{ml}$ of $1 \%$ SDS, $1 \% \beta$-mercaptoethanol, $0.01 \mathrm{M}$ sodium phosphate (pH 7.0) in a Dounce homogenizer fitted with a 'tight' pestle and then dialyzed overnight against $0.1 \%$ SDS, $0.1 \% \beta$-mercaptoethanol, $0.01 \mathrm{M}$ sodium phosphate (pH 7.0) for $12 \mathrm{~h}$ at $22^{\circ} \mathrm{C}$. Sucrose was added to a final concentration of $15 \%$ and the samples were heated in boiling water for $5 \mathrm{~min}$. Fifty $\mu$ l aliquots containing approx. $25 \mu \mathrm{g}$ of chromosomal proteins were electrophoresed on $0.6 \times 7.5 \mathrm{~cm}$, $7.5 \%$ polyacrylamide gels containing $0.1 \%$ SDS. A $0.6 \times 2 \mathrm{~cm}, 2.5 \%$ stacking gel containing $0.1 \%$ SDS was used. Electrophoresis was carried out for $7 \mathrm{~h}$ at $8 \mathrm{~mA} / \mathrm{gel}$ in a running buffer of $0.1 \% \mathrm{SDS}$, $0.1 \mathrm{M}$ sodium phosphate, $5 \mathrm{mM}$ EDTA (pH 7.0). Details of the procedure have been reported [5]. Following completion of electrophoresis, gels were immediately removed from the glass tubes and fixed in $12 \%$ trichloroacetic acid, $40 \%$ ethanol, $7 \%$ acetic acid at $22^{\circ} \mathrm{C}$ for $12 \mathrm{~h}$. Gels were then washed with $40 \%$ ethanol, $7 \%$ acetic acid, stained for $5 \mathrm{~h}$ at $37^{\circ} \mathrm{C}$ with $0.25 \%$ Coomassie brilliant blue in $40 \%$ ethanol, $7 \%$ acetic acid and electrophoretically destained in a Canalco "Quick gel" destainer using $10 \%$ ethanol, $7 \%$ acelic acid as a buffer. Gels were stored in $7 \%$ acetic acid.

The gels were scanned at $600 \mathrm{~nm}$ in a Beckman Acta II spectrophotometer equipped with a linear gel transport. The areas under the scan were integrated with a planimeter to determine the relative amounts of protein in discrete molecular weight regions of the gels and to correct for differences in absolute amounts of protein present in each gel. Within the narrow range of protein concentrations used in these electrophoretic fractionations, the amount of Coomassie brilliant blue stain bound (absorption) varied in a linear fashion with the protein concentration applied to the gels as determined by the method of Lowry [20].

After scanning, each gel was frozen in dry ice, fractionated into $1 \mathrm{~mm}$ slices, each slice was placed in a liquid scintillation counting vial containing $0.2 \mathrm{ml}$ of $30 \% \mathrm{H}_{2} \mathrm{O}_{2}$ and the gel slices were solubilized by heating at $37^{\circ} \mathrm{C}$ for $12 \mathrm{~h}$. Fractions containing specific 


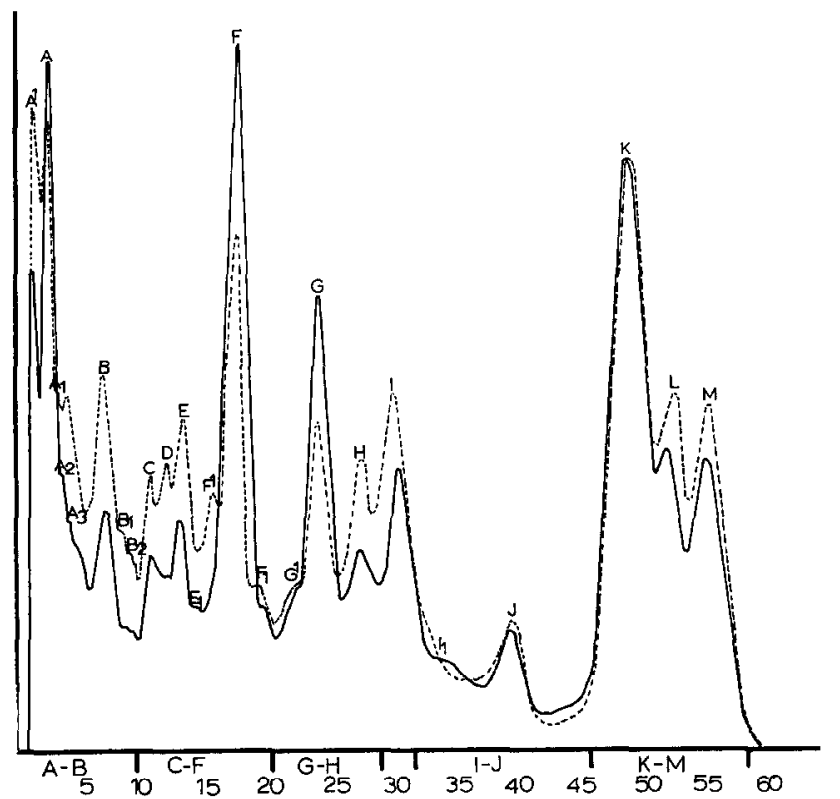

Fig. 1. Abscissa: fraction; ordinate: $\mathrm{OD}_{600}$. SDS polyacrylamide gel electrophoretic banding patterns of chromosomal proteins from -.. normal and -..., SV40 transformed WI38 human diploid fibroblasts, scanned at $600 \mathrm{~nm}$.

Twentyfive $\mu \mathrm{g}$ of protein were applied to each gel; the gels were electrophoresed for $7 \mathrm{~h}$ at $8 \mathrm{~mA} / \mathrm{gel}$, fixed, stained, destained and scanned, as described in Materials and Methods. Twentythree discrete bands were identified in alphabetical order from high to low molecular weight regions of the gels. The areas under the scan were integrated in order to estimate relative protein content in the five arbitrarily selected gel sections.

marker bands were identified to facilitate correlating the distribution of proteins and radioactivity in the gels. The fractions were counted in a Triton X-100toluene-liquifluor $(1: 2: 0.126)$ cocktail in a Nuclear Chicago Isocap/300 liquid scintillation spectrometer. Corrections for ${ }^{82} \mathrm{P}$ spillover in double-labelled samples were calculated by means of prepared standards.

\section{RESULTS}

Nonhistone chromosomal proteins of normal and SV40 transformed human diploid fibroblasts

Initially, the nonhistone chromosomal proteins associated with the genome of normal and SV40 transformed WI38 human diploid fibroblasts were examined. Chromatin was isolated from purified nuclei, dissociated and chromosomal proteins were fractionated electrophoretically according to molecular weight on SDS polyacrylamide gels. The polyacrylamide gel electrophoretic banding patterns of chromosomal proteins from normal and SV40 transformed cells are shown in fig. 1. Peaks are identified alphabetically (A through $\mathrm{M}$ ) and arbitrarily divided into five regions (A-B, C-F, G-H, I-J, K-M). The molecular weight ranges of chromosomal proteins which migrate in each of these regions are indicated in table 1. Peaks I, K, L, and $M$ represent histone

Table 1. Molecular weight ranges of chromosomal proteins fractionated by SDS gel electrophoresis

\begin{tabular}{lccccc}
\hline Gel regions ... & A-B & C-F & G-H & I-J & K-M \\
\hline $\begin{array}{l}\text { Molecular } \\
\text { weight (MW) } \\
\text { (Daltons) }\end{array}$ & $1500-90000$ & $900-55000$ & $550-38000$ & $350-20000$ & $200-10000$ \\
\hline
\end{tabular}

Molecular weight ranges for the 5 selected gel sections shown in figs 1-4 were estimated through the use of the following marker proteins: phosphorylase A (MW 94000 ), bovine serum albumin (MW 68 000), ovalbumin (MW 43 000), myoglobin (MW 14 200) and cytochrome $c$ (MW 12400 ) in addition to two histone fractions ... $\mathrm{f} 3$ (MW 15000) and f $2 \mathrm{a} 1$ (MW 11300 ). f1, f2b and $\mathrm{f} 2 \mathrm{a} 2$ appeared to migrate anomalously as reported by other workers [4]. Although actual molecular weights of $f 1, \mathrm{f} 2 \mathrm{~b}$ and $\mathrm{f} 2 \mathrm{a} 2$ are 21000,14000 and 15000 respectively, they migrate in the 37000,15000 and 14000 molecular weight regions of the gels. 
Table 2. Composition of chromatin proteins of WI38 and SV40 transformed WI38 human diploid fibroblasts as separated by SDS-gel electrophoresis

\begin{tabular}{llllll}
\hline & & \multicolumn{4}{c}{ Gel regions (\% of total NHP) } \\
\cline { 3 - 6 } & NHP/HP & A-B & C-F & G-H & I-J (f 1 excluded) \\
\hline WI38 & 1.8 & 25 & 35 & 25 & 15 \\
SV-WI38 & 1.8 & 33 & 31 & 21 & 15 \\
\hline
\end{tabular}

Calculation of relative protein content of the histones and nonhistone chromosomal proteins and the distribution of these proteins within various molecular weight regions of the gels were based on planimeter analysis of gel scans shown in fig. 1. Nonhistone chromosomal proteins (NHP). Histone proteins (HP). Each figure represents an average of at least four determinations and the range of values did not exceed $5 \%$.

polypeptides while the remaining peaks represent nonhistone chromosomal proteins. Peak I contains $\mathrm{f} 1$ histones. Although the molecular weight of this fraction is known to be 21000 , it appears to migrate anomalously in SDS gels (mol. wt 37000 ). Similar results were reported by other authors [4]. Peak K contains $\mathrm{f} 3$ and $\mathrm{f} 2 \mathrm{~b}$ (mol. wt 15000 ) histones, peak $L$ contains f $2 \mathrm{a} 2$ (mol. wt 14000 ) histones and peak $M$ contains f $2 \mathrm{al}$ (mol. wt 11300 ) histones. In spite of the apparent migration of $\mathrm{f} 2 \mathrm{a} 2$ and $\mathrm{f} 2 \mathrm{~b}$ in the 14000 and 15000 molecular weight regions respectively of these SDS polyacrylamide gels, their actual molecular weights based on amino acid sequence analysis are 15000 and 14000 . Evidence that peaks I, K, $L$ and $M$ represent histone polypeptides includes $(a)$ the identical migration of purified histone standards electrophoresed in this gel system under similar conditions; $(b)$ the disappearance of these peaks following extraction of chromatin with diluted mineral acid $(0.25$ normal $\mathrm{HCl}$ or 0.4 normal $\mathrm{H}_{2} \mathrm{SO}_{4}$ ) and (c) the loss of $\mathrm{f} 1$ histones during nuclear isolation at low pH [15].

It is apparent (fig. 1) that there are defined variations in the relative amounts of protein present in specific molecular weight classes of nonhistone chromosomal proteins from normal and SV40 transformed cells. While peaks $F$ and $G$ are more pronounced in normal WI38 fibroblasts, peaks B, C, D, E, and $H$ are more pronounced in SV40 transformed cells.

Table 2 indicates the nonhistone chromosomal protein: histone ratios in normal and SV40 transformed WI38 cells as well as the relative amounts of chromosomal proteins which migrate in each molecular weight region of the SDS polyacrylamide gels shown in fig. 1. The nonhistone chromosomal protein:histone ratios in normal and SV40 transformed cells show that the relative amounts of histone and nonhistone chromosomal protein associated with the genome in both cell types are similar; however, there are significant variations in the distribution of nonhistone chromosomal proteins in the various molecular weight classes. Specifically, the relative amount of nonhistone chromosomal proteins in normal WI38 cells is highest in region $\mathrm{C}-\mathrm{F}$ and in SV40 transformed WI38 cells is highest in region A-B.

\section{Metabolism of nonhistone chromosomal proteins in normal and SV40 transformed human diploid fibroblasts}

The rates of nonhistone chromosomal protein synthesis in normal and SV40 transformed WI38 human diploid fibroblasts were assayed by pulse-labelling cells for 60 min with either ${ }^{3} \mathrm{H}$-L-leucine or ${ }^{3} \mathrm{H}-\mathrm{L}-$ 
similar amounts in both normal and transformed cells, peaks $\mathrm{E}$ and $\mathrm{H}$, exhibit a markedly decreased rate of synthesis in the transformed cells. While it can be argued that modifications in the molecular weight distribution of chromosomal proteins may, at least in part, be attributed to proteolytic degradation, this is unlikely since nuclei and chromatin were isolated in the presence of TPCK, a protease inhibitor. In this context, we have observed shifts in the synthesis and relative content of nonhistone chromosomal proteins from the higher to lower molecular weight regions of SDS polyacrylamide gels when nuclei and chromatin are isolated in the absence of TPCK. Such variations are more pronounced in SV40 transformed than in normal WI38 cells and consequently could be mistaken for bona fide variations in the chromosomal proteins associated with the genome (unpublished observation).

The variations in nonhistone chromosomal protein phosphorylation described in these studies are in agreement with quantitative and qualitative differences in the phosphorylation of purified nonhistone chromosomal phosphoproteins associated with transformation of human diploid cells by DNA tumour viruses [23]. Since nonhistone chromosomal protein phosphorylation has been implicated as a mechanism by which transcription may be modified [12, 31], a regulatory involvement of the phenomenon is implied.

Additional modifications in the composition and metabolism of nonhistone chromosomal proteins which constitute the genome of normal and SV40 transformed human diploid cells may in fact exist. However, the resolution afforded by the protein fractionation methods utilized in these studies may not be sufficiently sensitive for detection of changes in microheterogeneity within individual nonhistone chromosomal protein molecular weight classes.
The observed differences in the nonhistone chromosomal protein components of the genome of normal and SV40 transformed WI38 human diploid fibroblasts are consistent with findings of Zardi et al. [42] which indicate immunological variations in the chromatin of both cell types. Taken together with evidence which suggests that nonhistone chromosomal proteins play a key role in the regulation of DNA-dependent RNA synthesis $[9,13,26-31,39,41]$, one can speculate that the observed modifications in nonhistone chromosomal proteins of SV40 transformed WI38 human diploid fibroblasts may be functionally related to alterations in gene expression associated with viral transformation. Such reasoning is further supported by the recent findings that changes in the synthesis of nonhistone chromosomal proteins occur following infection of several types of eukaryotic cells with oncogenic RNA and DNA viruses [16, 18, 24, 34]. However, it remains to be elucidated whether the altered chromosomal proteins in SV40 transformed cells are associated with and regulate the host cell or integrated viral portion of the genome and whether the templates for these macromolecules are viral or cellular in origin.

The authors are indebted to Michelle Zornetzer for testing the protein markers for molecular weight estimations in SDS gels and to Jeudi Davis for culturing the cells.

These studies were supported by the following research grants: GB38349 and GB23921 from the NSF; F73UF from the ACS, and A4433 from the NRC of Canada.

Dr Krause's permanent address is Department of Biology, University of New Brunswick, Fredericton, New Brunswick, Canada.

\section{REFERENCES}

1. Allfrey, V C, Littau, V \& Mirsky, A E, Proc natl acad sci US 49 (1963) 419.

2. - Histones and nucleohistones (ed D M P Phillips) p. 241. Plenum Press, New York (1971).

3. Benjamin, T L, Current topics microbiol immun 59 (1972) 107. 
The genome in human diploid fibroblasts. I 169
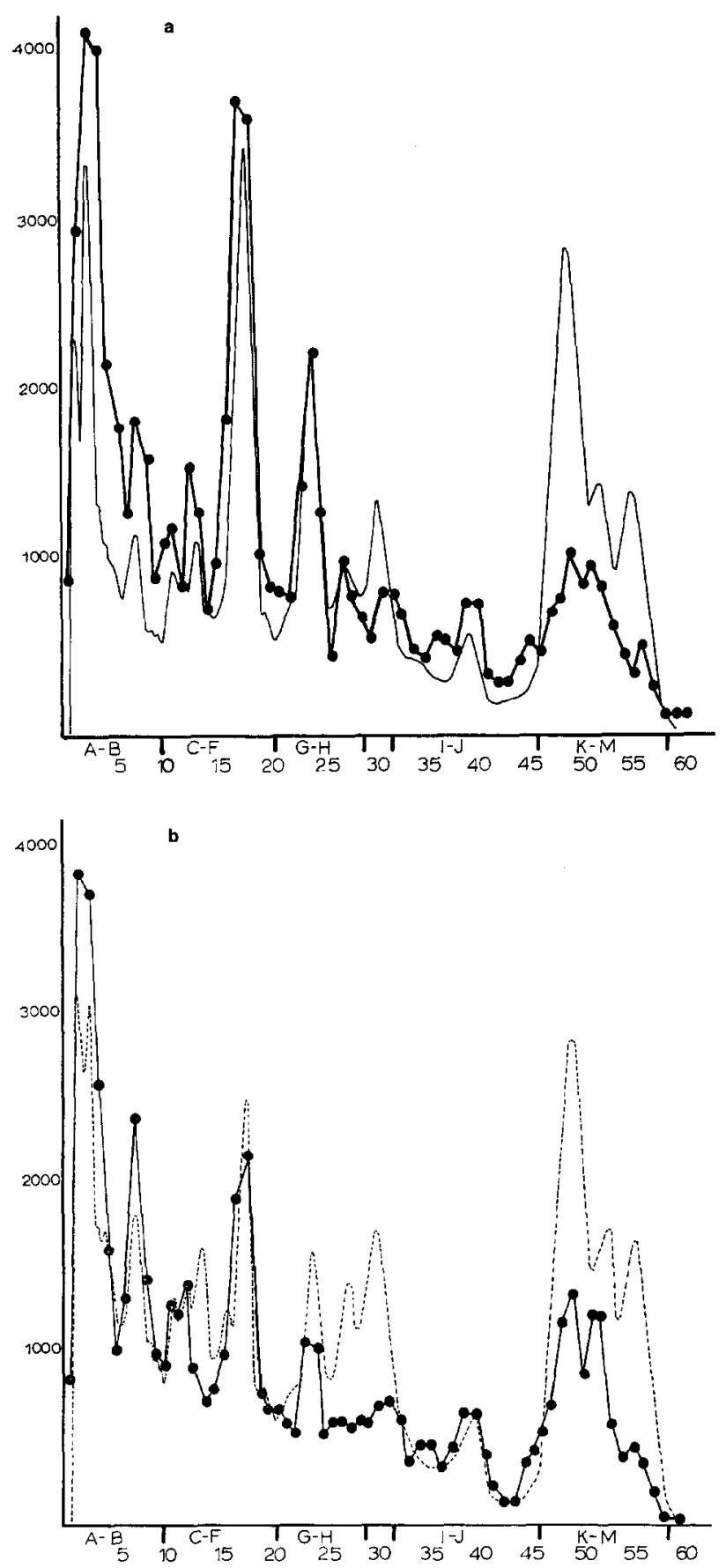

Fig. 2. Abscissa: fraction; ordinate: cpm $(-\bullet) ; \mathrm{OD}_{600}(-\longrightarrow)$ and $(\cdots \cdot)$.

The incorporation of ${ }^{3} \mathrm{H}$-leucine into chromosomal proteins of WI38 $(a)$ and SV40 transformed WI38 (b) human diploid fibroblasts. After scanning at $600 \mathrm{~nm}$ each gel was sliced into $1 \mathrm{~mm}$-thick sections, dispensed into scintillation counting vials, digested with $0.2 \mathrm{ml} 30 \% \mathrm{H}_{2} \mathrm{O}_{2}$ and counted in the ${ }^{8} \mathrm{H}$ window of a liquid scintillation spectrometer. Previously identified bands were marked on the vials in order to facilitate assignment of radioactivity profiles.

which migrate between fractions $10-20$ and $22-30$ is also indicated in fig. 3. The specific activities of nonhistone chromosomal proteins from normal and SV40 transformed
WI38 fibroblasts labelled with ${ }^{3} \mathrm{H}$-tryptophan and ${ }^{32} \mathrm{P}$ are compared in table 4 . An increased specific activity of the ${ }^{3} \mathrm{H}$-tryptophan-labelled nonhistone chromosomal poly- 
Table 4. Incorporation of ${ }^{3} \mathrm{H}$-leucine, ${ }^{3} \mathrm{H}$-tryptophan and ${ }^{32} \mathrm{P}$ per unit protein in the various molecular weight classes of nonhistone proteins of WI38 and SV transformed human diploid fibroblasts

\begin{tabular}{|c|c|c|c|c|c|c|c|c|c|c|c|c|c|}
\hline \multirow[t]{2}{*}{ Gel regions ... } & \multicolumn{3}{|c|}{$\begin{array}{l}\text { A-B } \\
\text { (cpm/OD unit) }\end{array}$} & \multicolumn{3}{|c|}{$\begin{array}{l}\mathrm{C}-\mathrm{F} \\
\text { (cpm/OD unit) }\end{array}$} & \multicolumn{3}{|c|}{$\begin{array}{l}\text { G-H } \\
\text { (cpm/OD unit) }\end{array}$} & \multicolumn{3}{|c|}{$\begin{array}{l}\text { I-J } \\
\text { (cpm/OD unit) }\end{array}$} & \multirow[b]{2}{*}{$\begin{array}{l}\text { Ave. } \\
{ }_{32}^{2} \mathrm{P}\end{array}$} \\
\hline & $\frac{\bar{\nabla}}{\stackrel{\vec{\nu}}{\Delta}}$ & 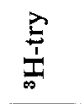 & స్లి & $\frac{\vec{\sigma}}{\frac{\vec{\nu}}{\vec{t}}}$ & $\underset{\infty}{\stackrel{1}{1}}$ & ఫ్ळ & 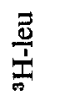 & 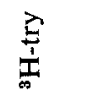 & 앯 & $\frac{\vec{D}}{\bar{D}}$ & 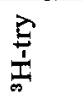 & 鄗 & \\
\hline \multirow{3}{*}{$\begin{array}{l}\text { WI38 } \\
\text { SV-WI38 } \\
\text { SV-induced } \\
\text { increase }\end{array}$} & 817 & 197 & 382 & 509 & 46 & 47 & 341 & 88 & 54 & 368 & 106 & 72 & 139 \\
\hline & 738 & 251 & 851 & 453 & 98 & 176 & 301 & 128 & 186 & 344 & 150 & 161 & 343 \\
\hline & None & $1.3 \times$ & $2.2 \times$ & None & $2.1 \times$ & $3.7 \times$ & None & $1.4 \times$ & $3.4 \times$ & None & $1.4 \times$ & $2.2 \times$ & $2.5 \times$ \\
\hline
\end{tabular}

The same protocol as in table 3 was used to calculate specific activities for each of the specified gel regions of the fractionated nonhistone chromosomal proteins. Each figure represents an average of at least four determinations and the range of values did not exceed $5 \%$.

peptides which migrate in regions $\mathrm{A}-\mathrm{B}$ (1.3-fold), C-F (2.1-fold), G-H (1.4-fold) as well as I-J (1.4-fold) is evident in the SV40 transformed cells. The specific activity figures account for variations in the protein content in each nonhistone chromosomal protein fraction. A corresponding increased phosphorylation of the nonhistone chromosomal proteins which migrate in these regions of the gels is reflected by a 2.2-3.7-fold increase in specific activity of ${ }^{32} \mathrm{P}$-labelled nonhistone chromosomal proteins. That ${ }^{32} \mathrm{P}$ incorporation solely reflects nonhistone chromosomal protein phosphorylation and does not represent nucleic acid synthesis was supported by the absence of significant levels of radioactivity in these gels when normal and SV40 transformed WI38 cells were labelled with ${ }^{14} \mathrm{C}$-thymidine and ${ }^{3} \mathrm{H}$-uridine. Some nucleic acids were found to enter the stacking gel (not shown) but only back-ground levels of radioactivity could be detected throughout the separating gel.

\section{Relationship between nonhistone chromosomal protein synthesis and DNA replication in SV40 transformed human diploid fibroblasts}

In continuously dividing populations of cells as well as in quiescent cells stimulated to proliferate, net synthesis of histones is restricted to the $S$ phase of the cell cycle and dependent on concomitant DNA replication. In contrast, nonhistone chromosomal proteins are synthesized throughout the cell cycle and their synthesis does not appear to be coupled with DNA replication. Previous studies from this laboratory [32, 33] have shown that the synthesis of nonhistone chromosomal proteins in normal WI38 human diploid fibroblasts is not inhibited when DNA replication is blocked with cytosine arabinoside $(40 \mu \mathrm{g} / \mathrm{ml})$ although the synthesis of histone during " $\mathrm{S}$ " phase is inhibited by $95 \%$. A direct effect of the drug on protein synthesis is unlikely since cytosine arabinoside does not affect the synthesis of total cellular proteins or nonhistone chromosomal proteins during the $\mathrm{G} 1$ phase of the cell cycle. To determine whether transformation of human diploid fibroblasts by a DNA tumour virus alters the relationship between nonhistone chromosomal protein synthesis and DNA replication, SV40 transformed WI38 human diploid fibroblasts were pretreated with cytosine arabinoside $(40 \mu \mathrm{g} / \mathrm{ml})$ for $15 \mathrm{~min}$ and then pulse-labelled for $60 \mathrm{~min}$ with ${ }^{3} \mathrm{H}$-L-leucine in the presence of cytosine arabinoside $(40 \mu \mathrm{g} / \mathrm{ml})$. The effect of SV40 viral transformation on the coupling of 

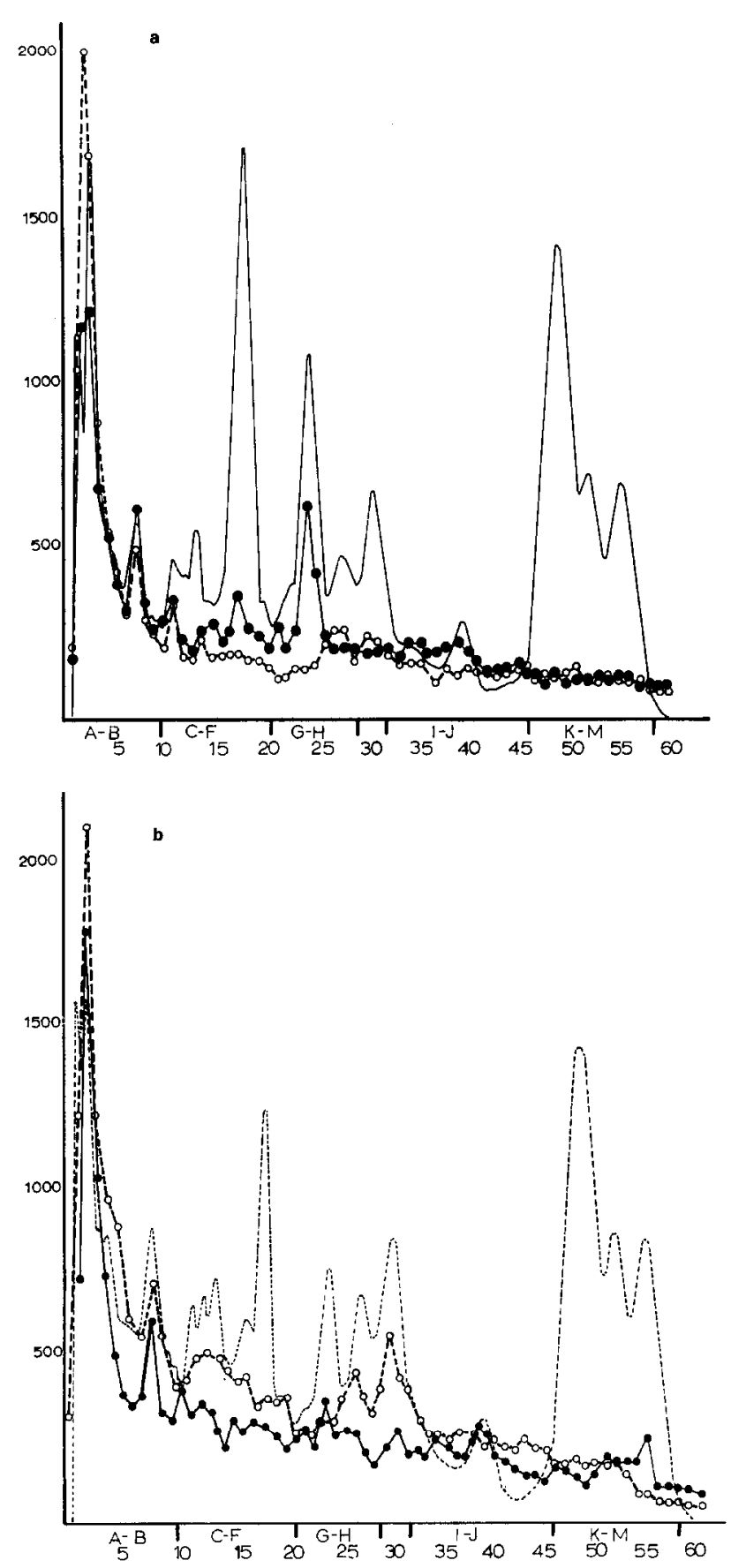

Fig. 3. Abscissa: fraction; ordinate: cpm $\left({ }^{3} \mathrm{H},-0 ;{ }^{32} \mathrm{P}, \mathrm{O}-\mathrm{O}\right) ; \mathrm{OD}_{\mathrm{600}}(--)$ and (-).

The incorporation of $\mathbf{e},{ }^{3} \mathrm{H}$-tryptophan and $O,{ }^{32} \mathrm{P}$ into chromosomal proteins of WI38 (a) and SV40 transformed WI38 (b) human diploid fibroblasts. The cells were double-labelled with the two precursors and processed as described in Materials and Methods. Integration of the OD scans and fractionation of the respective gels were carried out as in the previous experiments. The fractions were assayed in the ${ }^{8} \mathrm{H}$ and ${ }^{32} \mathrm{P}$ windows of a liquid scintillation spectrometer. Corrections for ${ }^{32} \mathrm{P}$ spillover into the ${ }^{8} \mathrm{H}$ window were carried out through the use of prepared standards and checked by recounting the same samples 4 weeks later to allow for $75 \%$ s2P decay. histone synthesis and DNA replication will be discussed in a subsequent communication [17]. In the present studies, cells were harvested immediately following labelling, chromatin was isolated and dissociated and chromosomal proteins were fractionated electrophoretically on SDS polyacrylamide gels. Fig. 4 indicates that cytosine arabinoside 


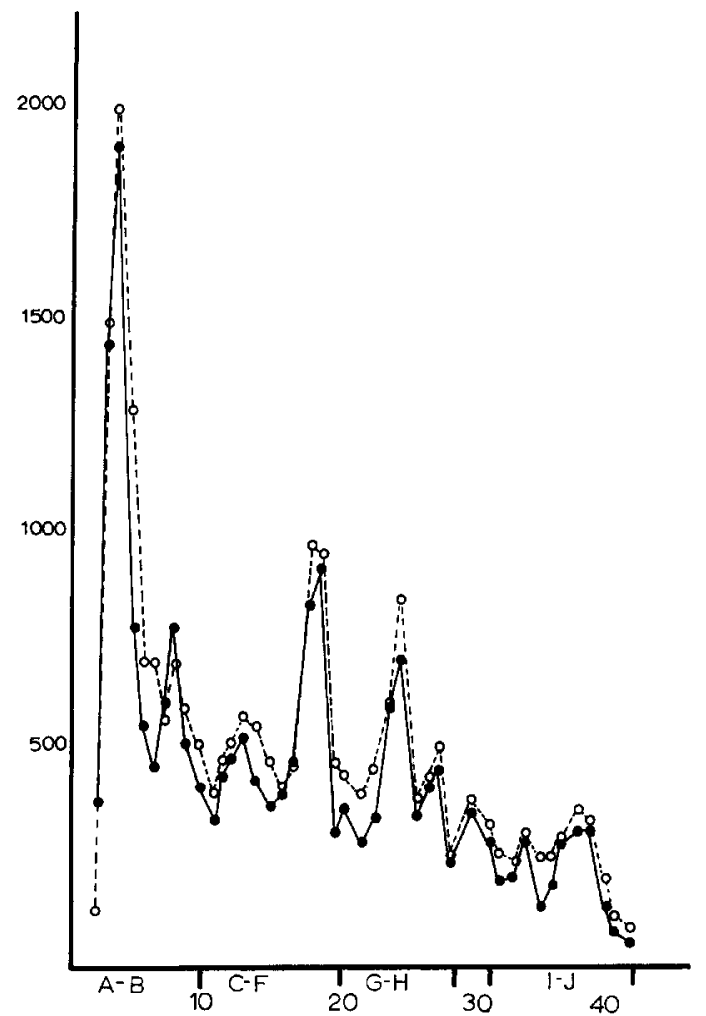

Fig. 4. Abscissa: fraction; ordinate: cpm.

The incorporation of ${ }^{\mathbf{3}} \mathrm{H}$-leucine into nonhistone chromosomal proteins of $\bullet$, control and $O$, cytosine arabinoside-treated (40 $\mu \mathrm{g} / \mathrm{ml}) \quad$ SV40 transformed WI38 human diploid fibroblasts. Cell treatment, labelling and fractionation of nonhistone chromosomal proteins were carried out as described in Materials and Methods.

does not inhibit the synthesis of the major molecular weight classes of nonhistone chromosomal polypeptides. Total specific activity figures actually show a slight increase in cytosine arabinoside-treated cells, $1200 \mathrm{cpm} / \mu \mathrm{g}$ NHP as compared with 920 $\mathrm{cpm} / \mu \mathrm{g}$ NHP in control cells, which could simply reflect pool size variations resulting from the inhibition of histone synthesis. These findings are consistent with a lack of coupling of nonhistone chromosomal protein synthesis and DNA replication in SV40 transformed human diploid cells.

\section{DISCUSSION}

The present studies indicate modifications in the composition and metabolism of nonhistone chromosomal proteins associated with the genome in WI38 human diploid fibroblasts transformed by SV40 virus. These modifications in the genome of normal and SV40 transformed WI38 cells are reflected by variations: $(a)$ in the relative quantity of specific molecular weight classes of nonhistone chromosomal proteins; (b) in the specific activity of defined molecular weight classes of nonhistone chromosomal polypeptides, and $(c)$ in the phosphorylation of specific molecular weight classes of nonhistone chromosomal proteins. A complete lack of coupling of nonhistone chromosomal protein synthesis and DNA replication in normal and SV40 transformed WI38 human diploid fibroblasts has also been described.

The most pronounced differences in the relative quantities of nonhistone chromosomal proteins of normal and SV40 transformed cells are observed in the 150000 90000 and $90000-55000$ molecular weight regions of SDS polyacrylamide gels. The presence of a prominent nonhistone chromosomal protein band (F) in the 65000 molecular weight region of the gel is consistent with evidence that nonhistone chromosomal proteins of a similar molecular weight constitute a major component of the genome in both HeLa [4] and CHO cells [8]. In agreement with differences in the relative amounts of protein present in nonhistone chromosomal proteins which migrate in the $150000-90000$ and 90000-55 000 molecular weight regions of SDS polyacrylamide gels corresponding variations in the synthesis of these polypeptides are also evident. In addition, two molecular weight classes of nonhistone chromosomal proteins which are present in 
similar amounts in both normal and transformed cells, peaks $\mathrm{E}$ and $\mathrm{H}$, exhibit a markedly decreased rate of synthesis in the transformed cells. While it can be argued that modifications in the molecular weight distribution of chromosomal proteins may, at least in part, be attributed to proteolytic degradation, this is unlikely since nuclei and chromatin were isolated in the presence of TPCK, a protease inhibitor. In this context, we have observed shifts in the synthesis and relative content of nonhistone chromosomal proteins from the higher to lower molecular weight regions of SDS polyacrylamide gels when nuclei and chromatin are isolated in the absence of TPCK. Such variations are more pronounced in SV40 transformed than in normal WI38 cells and consequently could be mistaken for bona fide variations in the chromosomal proteins associated with the genome (unpublished observation).

The variations in nonhistone chromosomal protein phosphorylation described in these studies are in agreement with quantitative and qualitative differences in the phosphorylation of purified nonhistone chromosomal phosphoproteins associated with transformation of human diploid cells by DNA tumour viruses [23]. Since nonhistone chromosomal protein phosphorylation has been implicated as a mechanism by which transcription may be modified [12, 31], a regulatory involvement of the phenomenon is implied.

Additional modifications in the composition and metabolism of nonhistone chromosomal proteins which constitute the genome of normal and SV40 transformed human diploid cells may in fact exist. However, the resolution afforded by the protein fractionation methods utilized in these studies may not be sufficiently sensitive for detection of changes in microheterogeneity within individual nonhistone chromosomal protein molecular weight classes.
The observed differences in the nonhistone chromosomal protein components of the genome of normal and SV40 transformed WI38 human diploid fibroblasts are consistent with findings of Zardi et al. [42] which indicate immunological variations in the chromatin of both cell types. Taken together with evidence which suggests that nonhistone chromosomal proteins play a key role in the regulation of DNA-dependent RNA synthesis $[9,13,26-31,39,41]$, one can speculate that the observed modifications in nonhistone chromosomal proteins of SV40 transformed WI38 human diploid fibroblasts may be functionally related to alterations in gene expression associated with viral transformation. Such reasoning is further supported by the recent findings that changes in the synthesis of nonhistone chromosomal proteins occur following infection of several types of eukaryotic cells with oncogenic RNA and DNA viruses [16, 18, 24, 34]. However, it remains to be elucidated whether the altered chromosomal proteins in SV40 transformed cells are associated with and regulate the host cell or integrated viral portion of the genome and whether the templates for these macromolecules are viral or cellular in origin.

The authors are indebted to Michelle Zornetzer for testing the protein markers for molecular weight estimations in SDS gels and to Jeudi Davis for culturing the cells.

These studies were supported by the following research grants: GB38349 and GB23921 from the NSF; F73UF from the ACS, and A4433 from the NRC of Canada.

Dr Krause's permanent address is Department of Biology, University of New Brunswick, Fredericton, New Brunswick, Canada.

\section{REFERENCES}

1. Allfrey, V C, Littau, V \& Mirsky, A E, Proc natl acad sci US 49 (1963) 419.

2. - Histones and nucleohistones (ed D M P Phillips) p. 241. Plenum Press, New York (1971).

3. Benjamin, T L, Current topics microbiol immun 59 (1972) 107. 
4. Bhorjee, J S \& Pederson, T P, Proc natl acad sci US 69 (1972) 3345.

5. - Biochemistry 12 (1973) 2766.

6. Bull, D, Taylor, A T, Austin, D M \& Jones, O H, Virology 57 (1974) 279.

7. Butel, J S, Teuethia, S S, Biswal, N \& BenyeshMelnick, M, In vitro 6 (1971) 335 .

8. Gerner, E W \& Humphrey, R M, Biochim biophys acta 331 (1973) 117.

9. Gilmour, R S \& Paul, J, FEBS lett 9 (1970) 242.

10. Hnilica, L S, McClure, M E \& Spelsberg, T C, Histones and nucleohistones (ed D M Phillips) p. 187. Plenum Press, New York (1971).

11. Huang, R C \& Bonner, J, Proc natl acad sci US 54 (1965) 960.

12. Kish, V \& Kleinsmith, L J, J biol chem 249 (1974) 750.

13. Kleinsmith, L J, Heidema, J \& Carroll, A, Nature 226 (1970) 1025.

14. Kostraba, N \& Wang, T Y, Exptl cell res 80 (1973) 291.

15. Krause, M O, Yoo, B Y \& MacBeath, L, Arch biochem biophys 164 (1974) 172 .

16. Krause, M O \& Stein, G S. Submitted for pubblication.

17. - Exptl cell res 92 (1975) 175.

18. Ledinko, L, Virology 54 (1973) 294.

19. Louie, A J \& Dixon, G H, Proc natl acad sci US 69 (1972) 1975.

20. Lowry, O H, Rosebrough, N J, Farr, A L \& Randall, R S, J biol chem 193 (1951) 265.

21. Moscovici, C \& Vogt, P K, Virology 35 (1968) 487.

22. Noonan, $\mathrm{K} D$ \& Burger, $M$ M, Progress in surface and membrane science vol. 8, p. 245. Academic Press, New York (1974).

23. Pumo, D, Kleinsmith, L J \& Stein, G S. In preparation.
24. Rovera, G, Baserga, R \& Defendi, V, Nature new biol 237 (1972) 240.

25. Scher, C D \& Todaro, G, Exptl cell res 68 (1971) 479.

26. Spelsberg, T C \& Hnilica, L, Biochem j 120 (1970) 435.

27. Spelsberg, T C, Wilhelm, J A \& Hnilica, L S, Subcell biochem 1 (1972) 107.

28. Stein, G S \& Farber, J, Proc natl acad sci US 69 (1972) 2918.

29. Stein, G S, Chaudhuri, S C \& Baserga, R, J biol chem 247 (1972) 3918.

30. Stein, G S \& Baserga, R, Adv cancer res 15 (1972) 287.

31. Stein, G S, Spelsberg, T C \& Kleinsmith, L J, Science 183 (1974) 817.

32. Stein, G S \& Borun, T W, J cell biol 52 (1972) 292.

33. Stein, G S \& Thrall, C L, FEBS lett 34 (1973) 35.

34. Stein, G S, Moscovici, G, Moscovici, C \& Mons, M, FEBS lett 38 (1974) 295.

35. Stein, G S \& Burtner, D, Biochim biophys acta. In press.

36. Taber, R, Wertheimer, R \& Golrick, J, J mol biol 80 (1973) 367.

37. Temin, H M \& Rubin, H, Virology 6 (1958) 669.

38. Temin, H M, Ann rev microbiol 25 (1971) 609 .

39. Teng, C, Teng, C \& Allfrey, V G, J biol chem 246 (1971) 3597.

40. Todaro, G, Green, H \& Goldberg, B, Proc natl acad sci US 51 (1964) 66.

41. Wang, T Y, Exptl cell res 53 (1968) 288.

42. Zardi, L, Lin, J \& Baserga, R, Nature new biol 245 (1973) 211.

Received June 5, 1974

Revised version received October 17, 1974 